\title{
The conservation and ecology of the British Virgin Islands endemic tree, Vachellia anegadensis
}

\author{
Sara Bárrios, Maria Dufke, Martin Hamilton, Robyn Cowan \\ Nancy Woodfield-Pascoe, Bo Dalsgard, Julie Hawkins and Colin Clubbe
}

\begin{abstract}
Numerous island species have gone extinct and many extant, but threatened, island endemics require ongoing monitoring of their conservation status. The small tree Vachellia anegadensis was formerly thought to occur only on the limestone island of Anegada in the British Virgin Islands and was categorized as Critically Endangered. However, in 2008 it was discovered on the volcanic island of Fallen Jerusalem, c. $35 \mathrm{~km}$ from Anegada, and in 2018 it was recategorized as Endangered. To inform conservation interventions, we examined the species' distribution, genetic population structure, dependency on pollinators and preferred habitat, and documented any threats. We found $V$. anegadensis to be locally widespread on Anegada but uncommon on Fallen Jerusalem and established that geographical location does not predict genetic differentiation amongst populations. Vachellia anegadensis produces the highest number of seed pods when visited by animal pollinators, in particular Lepidoptera. Introduced animals and disturbance by humans appear to be the main threats to $V$. anegadensis, and in situ conservation is critical for the species' long-term survival.
\end{abstract}

Keywords Acacia anegadensis, British Virgin Islands, Caribbean, Endangered, endemic, monitoring, reassessment, Vachellia anegadensis

\section{Introduction}

$\mathrm{B}$ iodiversity loss and species extinctions are ongoing, with a decline of most indicators of the state of biodiversity (Butchart et al., 2010; Ceballos et al., 2015; Pimm \& Joppa, 2015). Despite the political commitment shown by parties to the Convention on Biological Diversity to

SARA BÁRrios (Corresponding author, (1) orcid.org/0000-0002-6541-1295), Martin Hamilton (ㄷ) orcid.org/0000-0002-5127-8438), Robyn Cowan and Colin ClubBe (10 orcid.org/0000-0002-0532-1722) Royal Botanic Gardens, Kew, Richmond, TW9 3AE, UK. E-mail s.barrios@kew.org

Maria Dufke and Bo DalsGaard (@i) orcid.org/0000-0003-2867-2805) Centre for Macroecology, Evolution and Climate, GLOBE Institute, University of Copenhagen, Copenhagen, Denmark

Nancy Woodfield-Pascoe National Parks Trust Virgin Islands, Tortola, British Virgin Islands

JULIE HawkINS (이 orcid.org/0000-0002-9048-8016) University of Reading, Reading, UK

Received 5 March 2020. Revision requested 29 July 2020.

Accepted 15 October 2020. First published online 20 September 2021. implement the Global Strategy for Plant Conservation, to stem the continuing loss of plant diversity (UNEP, 2000, 2010), plant species are also following this negative trend (Brummitt et al., 2015; Royal Botanic Gardens, Kew, 2016; Humphreys et al., 2019).

The Caribbean archipelago is a global biodiversity hotspot, with high levels of endemism and a flora that is threatened primarily by habitat conversion for agriculture and livestock farming (Myers, 1988; IPBES, 2018). To tackle the conservation deficit of the Caribbean (Maunder et al., 2008; Dryflor et al., 2016; Jestrow et al., 2018), the UK Overseas Territories team at the Royal Botanic Gardens, Kew, has been studying the flora of the Caribbean islands (Hamilton et al., 2016; Hamilton \& Bárrios, 2017) to assess the IUCN Red List status of species (IUCN, 2012) and to provide evidence for conservation interventions. A recent review has highlighted the knowledge gaps and conservation significance of plants in the UK Overseas Territories (Clubbe et al., 2020).

Vachellia anegadensis (Britton) Seigler \& Ebinger (synonym Acacia anegadensis Britton), a c. $8 \mathrm{~m}$ tall tree, was formerly believed to be endemic to the island of Anegada but a 2008 survey identified a population on the island of Fallen Jerusalem (Bárrios \& Hamilton, 2018). We undertook targeted surveys to collect data for evaluation of the distribution, population genetics, dependency on pollinators, and main threats to this species. Here we use these new data to develop conservation recommendations to safeguard the long-term survival of this threatened species. These data also formed part of the evidence to recategorize this species as Endangered (Bárrios \& Hamilton, 2018).

\section{Study area}

The British Virgin Islands, a UK Overseas Territory in the Caribbean Sea, comprises c. 240 mostly small and uninhabited islands and cays. The study sites are the islands of Anegada and Fallen Jerusalem (Fig. 1a). The $40 \mathrm{~km}^{2}$ Anegada, the most north-easterly island of the archipelago and the only one that is of non-volcanic origin, rises to c. $8 \mathrm{~m}$ altitude and is inhabited by c. 250 people, who live on the western part of the island, mostly around The Settlement. (Island Resources Foundation, 2013). The submerged limestone reef from which Anegada originated formed 119,000130,000 years ago (Hedges, 2011). The c. $1 \mathrm{~km}^{2}$ Fallen Jerusalem, an uninhabited volcanic island formed c. 80 


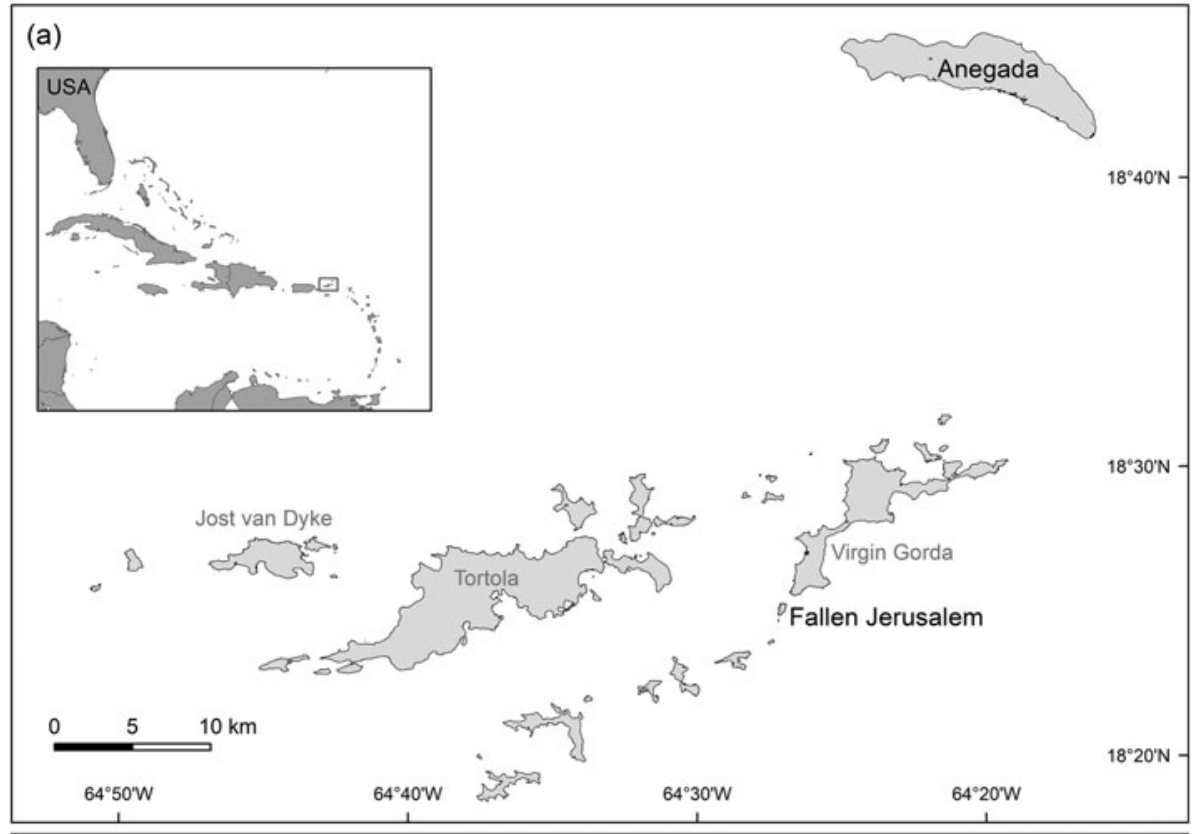

(b)

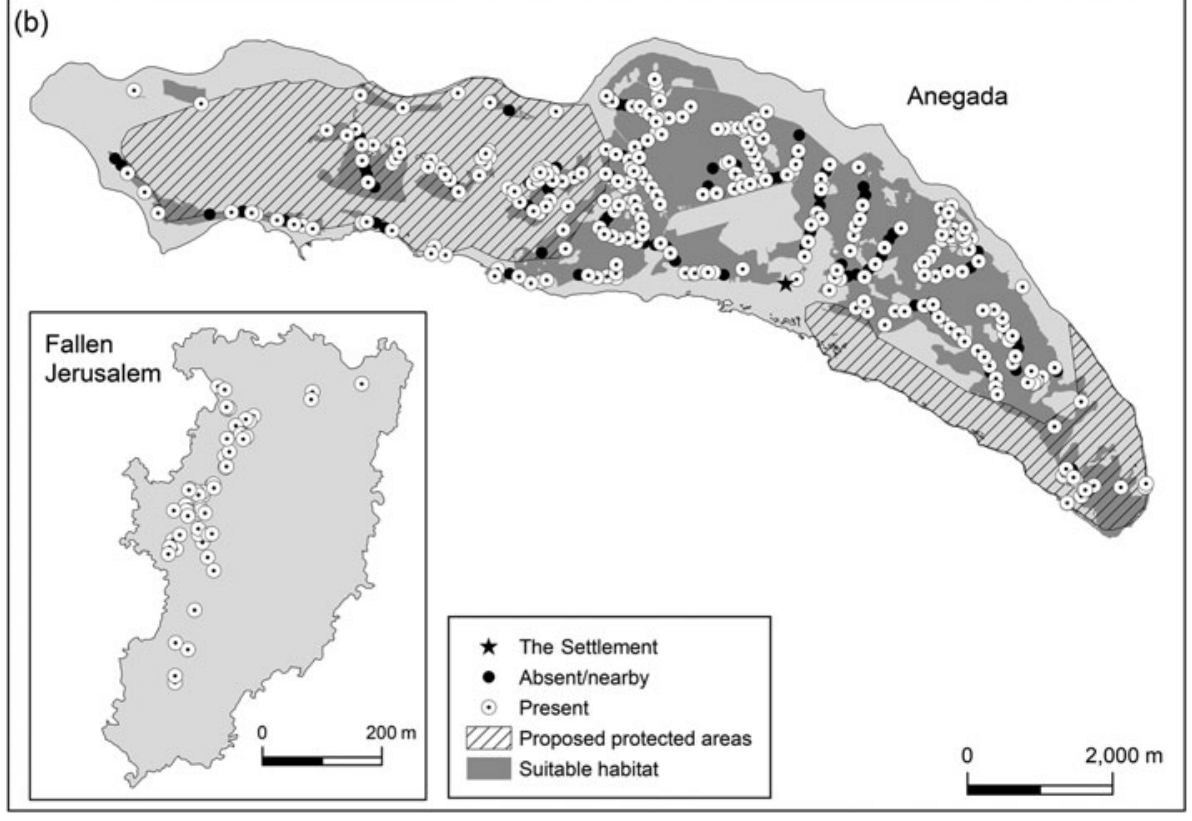

FIG. 1 (a) The British Virgin Islands, showing the locations of Anegada and Fallen Jerusalem, the two islands where the endemic tree Vachellia anegadensis occurs, and (b) distribution map of $V$. anegadensis on these two islands, as determined by our transect surveys. million years ago, rises to $50 \mathrm{~m}$ altitude and was designated a Bird Sanctuary in 1959 and a National Park in 1974 (Gardner et al., 2008).

\section{Methods}

\section{Data collection}

The distribution of $V$. anegadensis and the main threats to the species were determined by compiling information from literature and historical herbarium collections dating back to 1919 from JSTOR (2015), Missouri Botanical Garden (2015), New York Botanical Gardens (2015) and the UKOTs Online Herbarium (2020), and by carrying out field surveys during 2014-2019. In presence/absence transect surveys $5 \times 5 \mathrm{~m}$ quadrats were searched every $100 \mathrm{~m}$, for a minimum of six quadrats per transect, without limiting the number of quadrats per transect. Transects covered both islands, with a total of 20 transects. To ensure each transect was restricted to a single vegetation type, transects started 5-10 $\mathrm{m}$ from vegetation boundaries, as defined by the Anegada vegetation map (McGowan et al., 2006). Transect orientation was chosen randomly, using a random number in the range $1-360$, but avoided highly disturbed areas, although roads and paths were used for access and as transect lines. Voucher specimens of $V$. anegadensis were collected at the start of each transect, ensuring a collection every $1 \mathrm{~km}$ across the island, to document the full morphological 
diversity of this species, across all habitat types. Data were collected using two data entry forms, one for presence and one for absence. If $V$. anegadensis was not present in a quadrat but was up to $10 \mathrm{~m}$ away from the edge of the quadrat, this was noted. For all quadrats where $V$. anegadensis was present, the main threat, if present, was recorded as grazing, development, disturbance, clearing, invasive species, dumping or agriculture. Development was defined as construction, including roads or houses adjacent to quadrats, but also when signs of future development, such as development markers on the ground were observed. On Fallen Jerusalem, because of time restrictions, a single transect was undertaken with a southerly orientation, crossing the entire island. Threats were recorded in the same way as on Anegada. Data were compiled using BRAHMS 7 (University of Oxford, 2015).

Population structure was investigated using DNA extracted from leaf samples, which were taken from a randomly selected $V$. anegadensis in a quadrat containing the species c. every $500 \mathrm{~m}$ on Anegada. Leaf samples were collected from all $V$. anegadensis on Fallen Jerusalem because of the low number of individuals. A modified Doyle \& Doyle (1987) method was used to extract genomic DNA. Amplified fragment length polymorphism (AFLP) analysis was used to determine genetic diversity both within and between islands, to identify whether there were populations with unique genotypes and to infer population structure. AFLP reactions followed the Vos et al. (1995) protocol, modified for the AFLP Plant Mapping Protocol (Applied Biosystems Inc., Foster City, USA). Fragments of total genomic DNA were obtained by mixing two restriction enzymes, EcoRI and MseI, and double stranded adapters EcoRI and MseI in a restriction-ligation reaction. DNA was then amplified by PCR, using primers capable of annealing to the known adapters. DNA fragments, from 50 to 500 base pairs, were produced and separated by electrophoresis. DNA markers were recognized as either band present or absent (Vos et al., 1995; Frankham et al., 2002; Campbell et al., 2003; Meudt \& Clarke, 2007). Three primer combinations were selected, by analysing DNA fragments with Genemapper 4.o (Applied Biosystems, Foster City, USA), looking for high levels of polymorphism and reliable profiles. The primers used were CTA-(JOE-AAG); CAT-(FAM-ACT) and CTG-(NED-AGC).

Pollination studies were conducted on Anegada during April-July 2019. Visitation rates of hummingbirds and insects were monitored, separately, by direct sighting when the weather was dry and calm, during 6.00-14.00. Visitation by hummingbirds was monitored from $10 \mathrm{~m}$ in 30 minute observation periods; visitation by insects was monitored from $2 \mathrm{~m}$ in 10 minute observation periods. Visitation rate was calculated in two ways: (1) by counting the number of times we observed a given pollinator group to forage on the observed inflorescences (but ignoring the number of inflorescences visited during each feeding bout), divided by the number of observed inflorescences; and (2) by calculating the number of inflorescences visited during an observation period, divided by the number of observed inflorescences. The role of pollinators in fruit-setting was assessed experimentally. On 20 individuals of $V$. anegadensis, we recorded the proportion of 20 inflorescences bearing flowers that set fruit in each of two treatments: open and bagged inflorescences. For the open experiment, 20 newly opened inflorescences were marked with coloured string. For the bagged experiment, 20 late-stage buds were marked with coloured string and covered with a nylon mesh bag to exclude pollinators. The nylon mesh bags were removed as soon as the inflorescences had withered. After 4 weeks, fruit set was determined by counting the number of seed pods on each of the 40 inflorescences. The open and bagged inflorescences were paired on the 20 trees, to control for any potential micro-environmental and plant genetic effects on fruit set (Ricketts et al., 2004).

\section{Data analysis}

We imported the presence/absence dataset into ArcMap 10 (Esri, Redlands, USA) and incorporated presence occurrences into the Anegada vegetation map (McGowan et al., 2006), producing a final species distribution map (Fig. 1b). Data on the number of times each of the seven pre-identified threats affected $V$. anegadensis were compiled and summarized.

AFLP fragments were detected within the size range of 50-500 base pairs and scored for peak size by GeneMapper panels with a bin width of 1.0 base pairs. These peaks were converted to binary data (1, peak present; o, peak absent) and manually compared with the electropherograms to reconfirm presence or absence. Samples with results for all primers were combined into a single matrix. The matrix was analysed with STRUCTURE 2.3.4 (Pritchard et al., 200o), allowing us to infer population structure by simulating a series of genetic populations with a different mixture of individuals in each population. The model selected assumed admixture and independent allele frequency (Pritchard et al., 2000). We ran the analysis 10 times to be able to estimate the number of genetic clusters $(K)$, from 1 to 10 , with 100,000 steps burn-in period and 1,000,000 Markov chain Monte Carlo iterations. We uploaded the simulation results to the online resource STRUCTURE Harvester (Evanno et al., 2005), to determine the most likely number of genetic populations using Bayesian clustering methods. Finally, we mapped the inferred ancestry for each individual for the value of $K$ with the highest likelihood, in ArcMap.

For the pollination analysis, we used a Mann-Whitney $\mathrm{U}$ test to compare visitation rates by hummingbirds and insects. Subsequently, we used a Kruskal-Wallis test with a Dunn-Bonferroni post hoc test to examine differences in 
visitation rates among the four orders of insect visitors. We conducted the same tests for both measures of visitation rates. To test whether $V$. anegadensis has higher fruit/seed pod production when visited by pollinators, we used a Wilcoxon signed-rank test to compare seed pod production between the open and bagged pollination experiments. Statistical analyses were conducted using SPSS 26.o (IBM, New York, USA).

\section{Results}

Distribution and main threats We surveyed a total of 513 quadrats on Anegada; V. anegadensis was present in 218 quadrats, absent in 198, and within $10 \mathrm{~m}$ of 97 quadrats where the species was considered absent. On Fallen Jerusalem, we mapped and collected DNA samples from all of the 42 trees observed. On Anegada, we recorded the species across the island except in the north-west where $V$. anegadensis was absent from most quadrats (Fig. 1b). We confirmed the presence of $V$. anegadensis in limestone scrub, limestone thicket, limestone woodland, dune thicket, dune scrub, the edge of dry salt flats, human-disturbed areas, seasonally flooded woodland, the edge of mangroves, and foredune. On Fallen Jerusalem, we found that V. anegadensis occupies a central corridor on the west of the island (Fig. 1b), an area classified as mixed forest or scrubland with succulents (Kennaway et al., 2008). We observed feral goats, cattle and donkeys grazing on Anegada, and this was the most commonly observed threat to $V$. anegadensis, followed by development (Fig. 2). We recorded cattle mostly near The Settlement and inhabited areas, and observed goats and goat droppings across the entire island.

Genetic structure Data from 123 leaf samples were used for AFLP analysis. The three primer combinations amplified

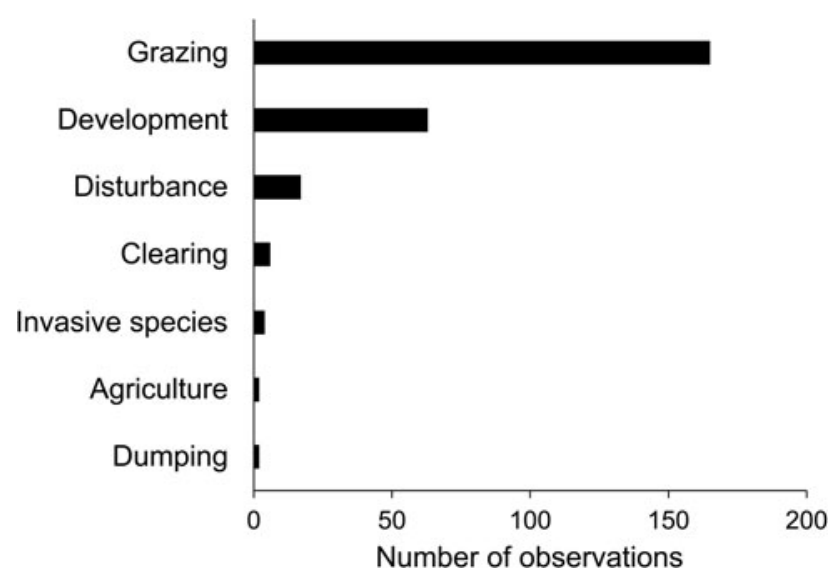

FIG. 2 Number of observations of seven potential, pre-identified threats affecting $V$. anegadensis on Anegada, recorded during our surveys.

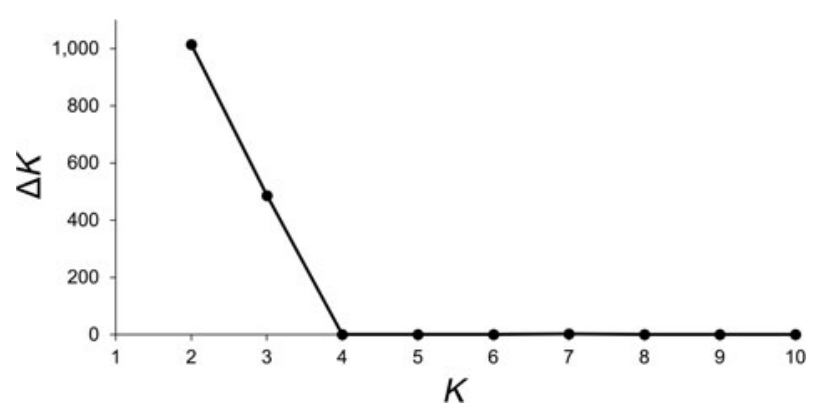

FIG. 3 Likelihood values $(\Delta K)$ obtained for $K=2$ to $K=10$, visualized with STRUCTURE Harvester (Evanno et al., 2005), to determine the most probable numbers of genetic clusters $(K)$ of $V$. anegadensis, across Anegada and Fallen Jerusalem (Fig. 1).

354 loci, of which $38 \%$ on Anegada and $48 \%$ on Fallen Jerusalem were polymorphic. The highest value for $\Delta K$ (likelihood values) was for $K=2$ (Fig. 3). Simultaneously, population structure analysis using Bayesian clustering methods revealed two genetic clusters $(K=2$; Fig. $4 \mathrm{a})$. When attempting to map each sample to the revealed genetic clusters, we were not able to assign a given population exclusively to a single cluster, and there were no clear geographical patterns (Fig. 4b).

Pollination For both measures of visitation rate, insects were more frequent visitors than hummingbirds (MannWhitney $U=5,138$ for feeding bouts/inflorescence/10 minutes, $U=5,092$ for number of visits/inflorescence/10 minutes, $\mathrm{P}<0.05)$. Among the insect visitors, lepidopterans were the most frequent visitors, and hymenopterans, dipterans and coleopterans were equally common visitors (Kruskal-Wallis test with a Dunn-Bonferroni post hoc test: $\mathrm{H}=109.18$ for feeding bouts/inflorescence/10 minutes, $\mathrm{H}=108.57$ for number of visits/inflorescence/10 minutes, $\mathrm{P}<0.05$; Fig. 5). A Wilcoxon signed-rank test showed that the fruit set of the two pollinator treatments differed significantly $(Z=-3,107$, $\mathrm{P}<0.05$;). Although the bagged inflorescence buds produced some seed pods (median o), the open pollinator treatment had a higher production of seedpods (median 10\%; Fig. 6).

\section{Discussion}

Although widespread on Anegada, and occurring on Fallen Jerusalem, the endemic tree $V$. anegadensis is threatened. On Anegada we confirmed previous studies, which documented it across the island (Clubbe et al., 2004), although less abundant in the north-west. Fallen Jerusalem has a deficit of historical records and research. This species is mainly found in the forested interior of the island, which also coincides with the area that has higher availability of freshwater and reduced salt spray (authors, pers. obs.). 
(a) Probability of genetic group allocation, inferred at $K=2$
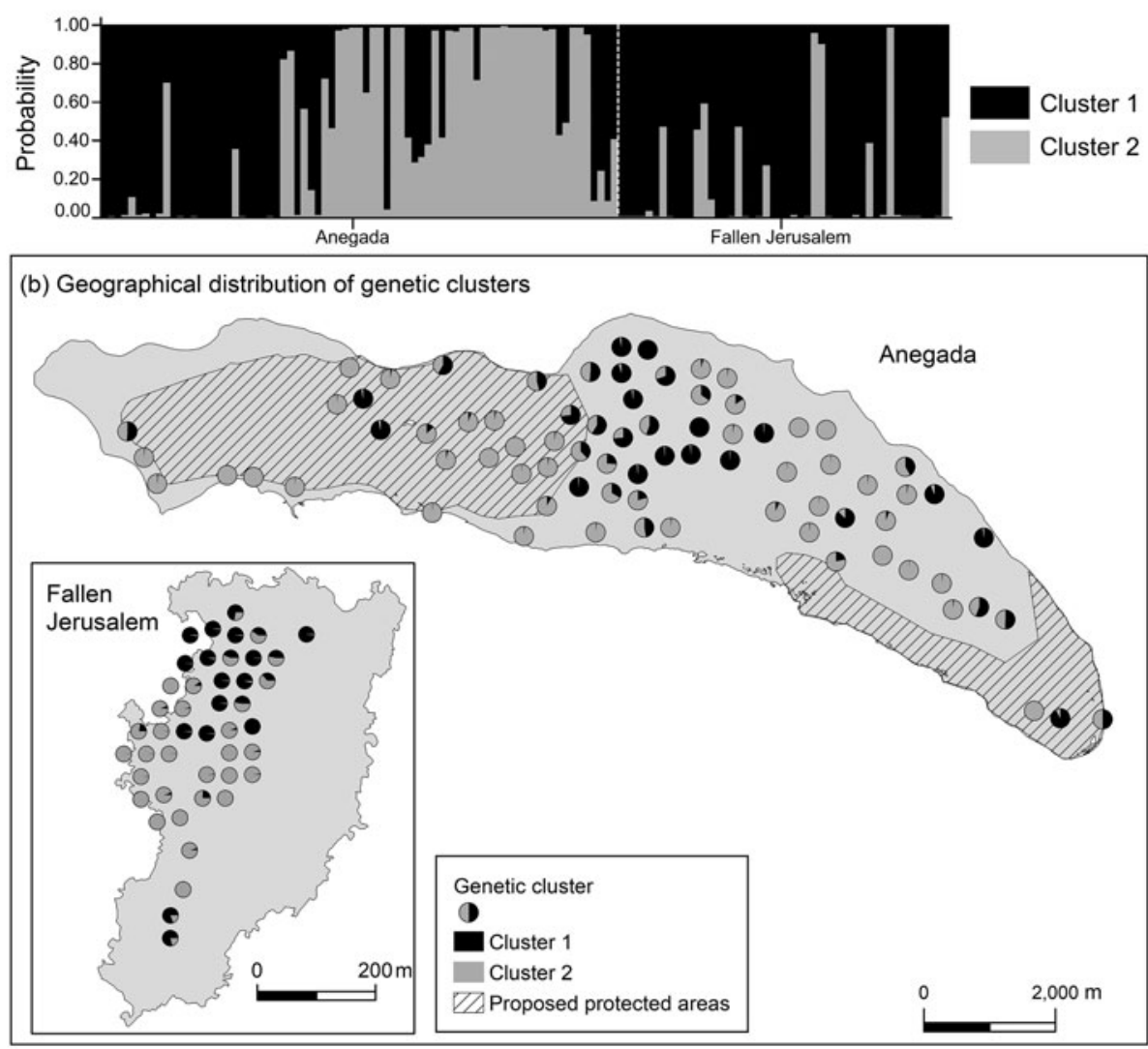

FIG. 4 (a) Probability of genetic cluster membership of

$V$. anegadensis individuals of Anegada and Fallen Jerusalem, inferred at $K=2$. The model assumed admixture and independent allele frequency. (b) Geographical distribution of genetic clusters for $K=2$. To visualize the individual samples we chose a non-overlapping display that approximates the exact location of the sample.
The analysis of population structure revealed distinct genetic clusters, but geographical location did not predict genetic differentiation. The genetic variability is equally spread, with no evidence of geographical clustering. Although studies of the genetic variation of tropical and Caribbean tree species suggest that geographically separate populations often have moderate levels of genetic differentiation (Loveless, 1992; Rivera-Ocasio et al., 2002), this is not the case for $V$. anegadensis. This could be the result of continuing gene flow between the two islands and/or of historical colonization events. For example, trees on Fallen Jerusalem could have originated from a colonization event by trees from Anegada, or vice-versa (Loveless, 1992; Comes \& Abbott, 1998; Aguirre-Planter et al., 2000; Hedges, 2011).

Feral animals and development appear to be the greatest threats to $V$. anegadensis on Anegada, in common with threats observed in other Caribbean regions (González-M. et al., 2018; Murray et al., 2020). Caribbean forests evolved in the absence of livestock and free from grazing by ungulates. Livestock were brought to the Caribbean c. 400 years ago by European settlers (Shepherd, 2009). On Anegada, livestock were historically kept within walled pens, but these were destroyed during the establishment of the airstrip and road network during the 1960s, allowing the livestock to roam freely across the island (Veitch, 1999; Island Resources Foundation,
2013). This had a devastating effect on the native flora (Schofield, 1989; Mitchell, 1999). Overgrazing reduces the number of seedlings, thus hindering regeneration. Overgrazing also depletes seed banks and, through changes to soil conditions, leads to compaction and reduction of top soil, which is essential for seed germination (Baker \& Reeser, 1972; Veitch, 1999; Meléndez-Ackerman, 2008). The impacts of these feral animals are not limited to the flora. The endemic Anegada iguana Cyclura pinguis, which disperses the seeds of $V$. anegadensis (Gerber, 1999; Bradley \& Gerber, 2005), has been faced with a shortage of food, as the native vegetation is consumed by feral animals (Veitch, 1999). Development of tourist infrastructure on Anegada is not yet comparable to that in other parts of the British Virgin Islands, but the 2007 Land Allocation Plan proposed a new settlement in the east, where the eastern salt ponds is the only protected area proposed on the island. Although this Land Allocation Plan has not yet been implemented, the development of a new settlement would have considerable impact on $V$. anegadensis as it would involve removal of more than half of the individuals on the island along with their habitat. During this study we observed indiscriminate road widening across the island, especially from The Settlement to Loblolly Bay, and illegal land clearance for farming on the western salt ponds, in both cases resulting in the death of $V$. anegadensis individuals. The threat of additional 
(a)

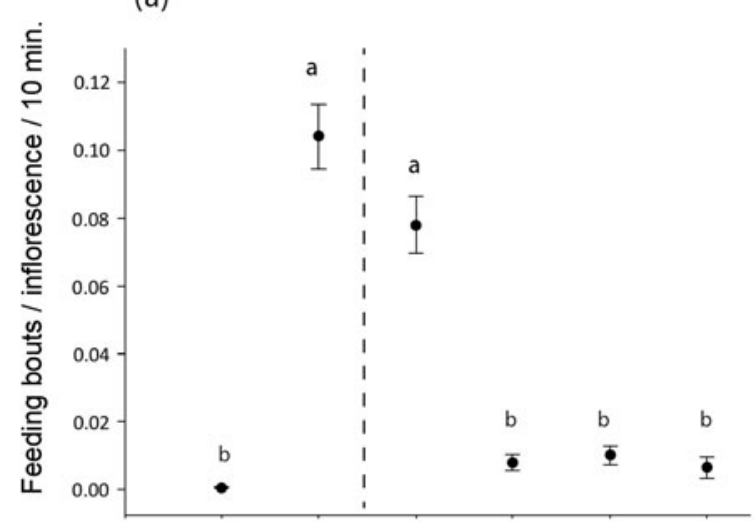

(b)

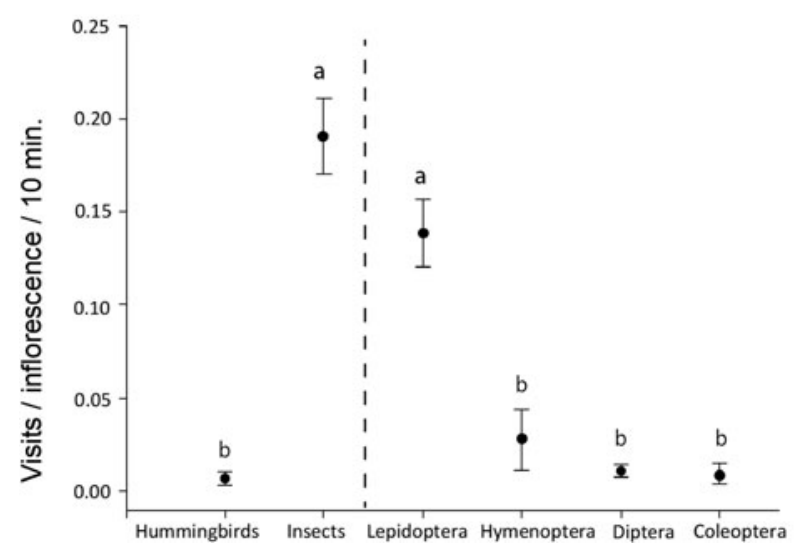

FIG. 5 Mean \pm SE visitation rate for hummingbirds, all insects and the four insect orders separately, as (a) number of feeding bouts/inflorescence/10 minutes, and (b) number of visits/ inflorescence/10 minutes. Different letters indicate a significant difference at $\mathrm{P}<0.05$ between groups; hummingbirds vs insects compared by Mann-Whitney U test (left of vertical line) and between insect groups compared by a Dunn-Bonferroni post hoc test following a Kruskal-Wallis test (right of vertical line).

development remains and would have serious implications for the future of $V$. anegadensis without adequate protection measures in place.

Although Fallen Jerusalem is a National Park it receives few visitors. However, some tourists hike on the island, and use the beach, which can cause disturbance to the vegetation. Another potential threat on Fallen Jerusalem is invasive rats Rattus rattus (Hamilton et al., 2019). Rats feed on seeds and seedlings, contributing to the extinction of plant species (Wolf et al., 2018). This alien species could be predating seeds and seedlings of $V$. anegadensis and may be the main reason why we did not observe recruitment on the island. Both islands are being affected by more frequent and more prolonged droughts, and more intense hurricanes, indicative of global climate change, and may be affected by future sea level rise (Hamilton, 2016; IPCC, 2018).

Vachellia anegadensis is visited by a variety of pollinators, including hummingbirds and insects belonging to several

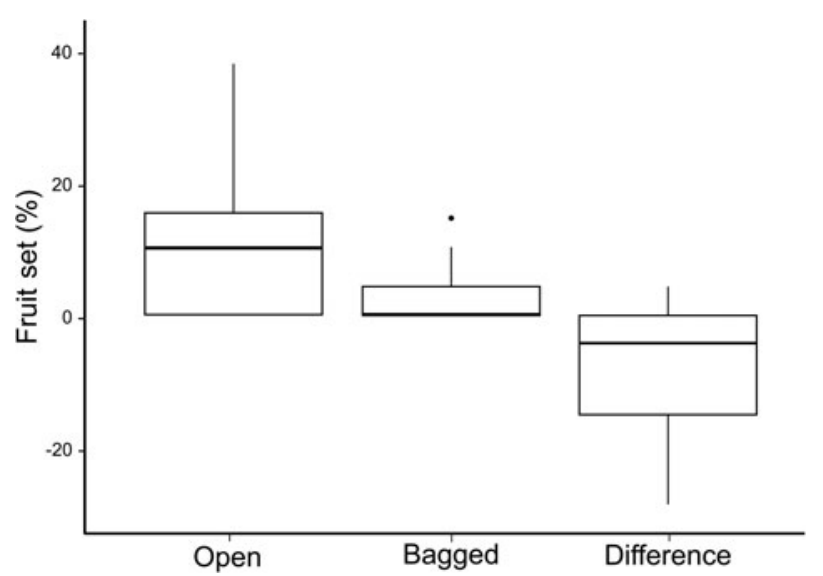

FIG. 6 Box plots showing per cent fruit set under two paired pollination treatments, open and bagged, on 20 individual $V$. anegadensis, and the difference in produced seed pods for the two treatments. In each box plot, the middle thick line indicates the median, box limits are the first and third quartiles, vertical lines indicate the data range and the dot indicates an outlier.

orders, similar to other Caribbean plants (Dalsgaard et al., 2009; Martin González et al., 2009). However, insects, especially butterflies, are the most frequent floral visitor. Vachellia anegadensis had a low seed pod production when pollinators were excluded, indicating either that the tree may selfpollinate or be wind pollinated, as the nylon bags only excluded pollinators. The significantly higher production of seed pods in the absence of exclusion bags indicates the importance of pollinators, especially butterflies, for successful reproduction and thus the need for this to be considered in conservation strategies for $V$. anegadensis.

We recommend that a conservation strategy for $V$. anegadensis should aim to maintain the species' present levels of genetic variability, reduce the pressure from threats and help maintain suitable habitat. These aims would be aided by the legal establishment of the protected areas proposed on Anegada in the Protected Areas System Plan (Lloyd et al., 2008). Long-standing land issues need to be resolved to manage these areas successfully for biodiversity and livelihoods. There is a pressing need to address the greatest threat to $V$. anegadensis, feral livestock that roam freely across the island. Some of the livestock do not seem to have owners, and owners of free-ranging livestock do not appear willing to tether them. The Protection of Trees and Conservation of Soil and Water Ordinance (Gardner et al., 2007), which prohibits grazing of livestock in protected areas, is a mechanism that could address this issue once the protected areas are approved. In addition, some areas designated as proposed protected areas, which are uninhabited, need to be temporarily fenced, to prevent access by feral animals and to promote vegetation regeneration. Monitoring of $V$. anegadensis, and of the species' pollinators and seed dispersers, is required, and also monitoring of the invasive alien plants Cryptostegia 
madagascariensis Bojer ex Decne. and Kalanchoe pinnata (Lam.) Pers, which we observed to be spreading from The Settlement. Studies on other islands in the Caribbean have shown that isolation of vegetation is an effective in situ conservation measure (Baker \& Reeser, 1972; Debrot \& de Freitas, 1993; Wittenberg \& Cock, 2001). These proposed conservation measures need to be incorporated into a species management plan for $V$. anegadensis, to guide conservation interventions and to ensure the long-term survival of this threatened endemic species. Such a document could also provide a useful model to guide the conservation of other threatened Caribbean endemic plants.

Acknowledgements This research was sponsored by the Mohamed bin Zayed Species Conservation Fund (project number: 13257818) and the Bentham-Moxon Trust. MD and BD thank the Danish National Research Foundation for its support of the Center for Macroecology, Evolution and Climate, GLOBE Institute, University of Copenhagen, Denmark (grant number DNRF96). BD thanks Independent Research Fund Denmark (grant no. 0135-00333B). SB thanks Steven Bachman for GIS support and the Director of the National Parks Trust of the Virgin Islands, Cassander Titley-O'Neal, for useful discussion on conservation issues in the British Virgin Islands. We thank all staff of the National Parks Trust of the Virgin Islands for facilitating this work.

Author contributions Study design: $\mathrm{SB}, \mathrm{RC}, \mathrm{MAH}, \mathrm{CC}, \mathrm{MD}, \mathrm{BD}$; fieldwork: SB, MAH, MD; data analysis: $\mathrm{SB}, \mathrm{RC}, \mathrm{CC}, \mathrm{JH}, \mathrm{MD}, \mathrm{BD}$, writing: $\mathrm{SB}, \mathrm{CC}, \mathrm{MD}, \mathrm{BD}$; revision: all authors.

\section{Conflicts of interest None.}

Ethical standards This research abided by the Oryx guidelines on ethical standards.

\section{References}

Aguirre-Planter, E., Furnier, G.R. \& Eguiarte, L.E. (2000) Low levels of genetic variation within and high levels of genetic differentiation among populations of species of Abies from southern Mexico and Guatemala. American Journal of Botany, 87, 362-371.

Baker, J.K. \& Reeser, D.W. (1972) Goat Management Problems in Hawaii Volcanoes National Park: A History, Analysis and Management Plan. National Park Service, USA.

Bárrios, S. \& Hamilton, M.A. (2018) Acacia anegadensis. In The IUCN Red List of Threatened Species 2018. dx.doi.org/10.2305/IUCN. UK.2018-1.RLTS.T43894A125646453.en [accessed 3 July 2019].

Bradley, K.A. \& Gerber, G.P. (2005) Conservation of the Anegada iguana (Cyclura pinguis). Iguana, 12, 78-85.

Brummitt, N.A., Bachman, S.P., Griffiths-Lee, J., Lutz, M., MoAt, J.F., FARJON, A. et al. (2015) Green plants in the red: a baseline global assessment for the IUCN Sampled Red List Index for plants. PLOS ONE, 10, eo135152.

Butchart, S.H.M., Walpole, M., Collen, B., van Strien, A., Scharlemann, J.P.W., Almond, R.E.A. et al. (2010) Global biodiversity: indicators of recent declines. Science, 328, 1164-1168.

Campbell, D., Duchesne, P. \& Bernatchez, L. (2003) AFLP Utility for population assignment studies: analytical investigation and empirical comparison with microsatellites. Molecular Ecology, 12, 1979-1991.

Ceballos, G., Ehrlich, P.R., Barnosky, A.D., García, A., Pringle, R.M. \& Palmer, T.M. (2015) Accelerated modern human-induced species losses: entering the sixth mass extinction. Science Advances, 1, e1400253.

Clubbe, C., Ainsworth, A.M., Bárrios, S., Bensusan, K., Brodie, J., Cannon, P. et al. (2020) Current knowledge, status, and future for plant and fungal diversity in Great Britain and the UK Overseas Territories. Plants, People, Planet, 2, 557-579.

Clubbe, C., Gillman, M., Acevedo-Rodríguez, P. \& Walter, R. (2004) Abundance, distribution and conservation significance of regionally endemic plant species on Anegada, British Virgin Islands. Oryx, 38, 342-346.

Comes, H.P. \& Аввотт, R.J. (1998) The relative importance of historical events and gene flow on the population structure of a Mediterranean ragwort, Senecio gallicus (Asteraceae). Evolution, $52,355-367$.

Dalsgaard, B., Martín González, A.M., Olesen, J.M., Ollerton, J., Timmermann, A., Andersen, L.H. \& Tossas, A.G. (2009) Plant-hummingbird interactions in the West Indies: floral specialisation gradients associated with environment and hummingbird size. Oecologia, 159, 757-766.

Debrot, A.O. \& de Freitas, J.A. (1993) A comparison of ungrazed and livestock-grazed rock vegetations in Curacao. Biotropica, 25, 270-280.

Doy le, J.J. \& Doyle, J.L. (1987) A rapid DNA isolation procedure for small quantities of fresh leaf tissue. Phytochemical Bulletin, 19, 11-15.

Dryflor, K.B.-R., Delgado-Salinas, A., Dexter, K.G., Linares-Palomino, R., Oliveira-Filho, A., Prado, D. et al. (2016) Plant diversity patterns in neotropical dry forests and their conservation implications. Science, 353, 1383-1387.

Evanno, G., Regnaut, S. \& Goudet, J. (2005) Detecting the number of clusters of individuals using the software STRUCTURE: a simulation study. Molecular Ecology, 14, 2611-2620.

Frankham, R., Briscoe, D.A. \& Ballou, J.D. (2002) Introduction to Conservation Genetics. Cambridge University Press, Cambridge, UK.

Gardner, L., Smith-Aвbott, J. \& Woodfield-Pascoe, N. (2007) British Virgin Islands Protected Areas System Plan 2007-2017. British Virgin Islands National Parks Trust, Tortola, British Virgin Islands.

Gardner, L., Smith- Аввотt, J., Woodfield, N.K., Lloyd, G., Smith-Аввотт, J. \& Woodfield, N.K. (2008) British Virgin Islands Protected Areas System Plan 2007-2017. Roadtown, Tortola, British Virgin Islands.

Gerber, G.P. (1999) Conservation of the Anegada Iguana, Cyclura pinguis. Field Research Report. Unpublished report to the British Virgin Islands National Parks Trust, Fauna \& Flora International, and the Zoological Society of San Diego, San Diego, USA.

González-M., R., Garcia, H., Isaacs, P., Cuadros, H., López-Camacho, R., Rodríguez, N. et al. (2018) Disentangling the environmental heterogeneity, floristic distinctiveness and current threats of tropical dry forests in Colombia. Environmental Research Letters, 13, 045007.

Hamilton, M.A. (2016) Boraginaceae Varronia rupicola (Urb.) Britton: biogeography, systematic placement and conservation genetics of a threatened species endemic to the Caribbean. $\mathrm{PhD}$ thesis, Birkbeck, University of London, London, UK.

Hamilton, M.A. \& BÁrrios, S. (2017) Puerto Rican Bank (British Virgin Islands \& Puerto Rico) June-July 2017 Fieldwork Report. Overseas Fieldwork Committee registration number 559-14. Royal Botanic Gardens, Kew, Richmond, UK.

Hamilton, M.A., Barrios, S.B., Clubbe, C.P., Corcoran, M.R., Gdaniec, A. \& Sanchez, M.D. (2016) Puerto Rican Bank (British Virgin Islands \& Puerto Rico) June-July 2016 Fieldwork Report. Overseas Fieldwork Committee registration number 559-11. Royal Botanic Gardens, Kew, Richmond, UK.

Hamilton, M.A., Bradley, K.A. \& Heller, T.M. (2019) British Virgin Islands June 2019 Fieldwork Report. Overseas Fieldwork 
Committee registration number 559-23. Royal Botanic Gardens, Kew, Richmond, UK.

HedGes, S.B. (2011) Biogeography of the west indies: an overview. In Biogeography of the West Indies: Patterns and Perspectives (eds C.A. Woods \& F.E. Sergile), pp. 15-30. CRC Press, Boca Raton, USA.

Humphreys, A.M., Govaerts, R., Ficinski, S.Z., Nic Lughadha, E. \& Vorontsova, M.S. (2019) Global dataset shows geography and life form predict modern plant extinction and rediscovery. Nature Ecology and Evolution, 3, 1043-1047.

IPBES (2018) Summary for Policymakers of the Regional Assessment Report on Biodiversity and Ecosystem Services for the Americas of the Intergovernmental Science-Policy Platform on Biodiversity and Ecosystem Services (eds J. Rice, C.S. Seixas, M.E. Zaccagnini \& M. BedoyaGai). Intergovernmental Science-Policy Platform on Biodiversity and Ecosystem Services, Bonn, Germany.

IPCC (2018) Summary for Policymakers. In Global Warming of $1.5^{\circ} \mathrm{C}$. An IPCC Special Report on the Impacts of Global Warming of $1.5{ }^{\circ} \mathrm{C}$ Above Pre-Industrial Levels and Related Global Greenhouse Gas Emission Pathways, in the Context of Strengthening the Global Response to the Threat of Climate Change, Sustainable Development and Efforts to Eradicate Poverty (eds V. Masson-Delmotte, P. Zhai, H.-O. Pörtner, D. Roberts, J. Skea, P.R. Shukla et al.).

Intergovernmental Panel on Climate Change, Geneva, Switzerland.

Island Resources Foundation (2013) An Environmental Profile of the Island of Anegada, British Virgin Islands. Tortola, British Virgin Islands and Washington, DC, USA.

IUCN (2012) Red List Categories and Criteria: Version 3.1. Second edition. IUCN Gland, Switzerland and Cambridge, UK.

Jestrow, B., Peguero, B., Jiménez, F., Verdecia, R., GonzÁlez-Oliva, L., Moya, C.E. et al. (2018) A conservation framework for the Critically Endangered endemic species of the Caribbean palm Coccothrinax. Oryx, 52, 452-463.

JSTOR (2015) Global Plants on JSTOR. plants.jstor.org [accessed 1 May 2015].

Kennaway, T.A., Helmer, E.H., Lefsky, M.A., Brandeis, T.A. \& Sherrill, K.R. (2008) Mapping land cover and estimating forest structure using satellite imagery and coarse resolution lidar in the Virgin Islands. Journal of Applied Remote Sensing, 2, 27.

Lloyd, G., Smith-Aввотt, J. \& Woodfield, N.K. (2008) British Virgin Islands Protected Areas System Plan 2007-2017. Tortola, British Virgin Islands.

Loveless, M.D. (1992) Isozyme variation in tropical trees: patterns of genetic organization. New Forests, 6, 67-94.

Martin González, A.M., Dalsgatrd, B., Ollerton, J., Timmermann, A., Olesen, J.M., Andersen, L. \& Tossas, A.G. (2009) Effects of climate on pollination networks in the West Indies. Journal of Tropical Ecology, 25, 493-506.

Maunder, M., Leiva, A., Santiago-Valentín, E., Stevenson, D., Acevedo-Rodríguez, P., Meerow, A. et al. (2008) Plant conservation in the Caribbean Island Biodiversity Hotspot. The Botanical Review, 74, 197-207.

McGowan, A., Broderick, A.C., Clubbe, C.P., Gore, S., Godley, B.J., Hamilton, M.A. et al. (2006) Darwin Initiative Action Plan for the Coastal Biodiversity of Anegada, British Virgin Islands. seaturtle. $\mathrm{org} / \mathrm{mtrg} / \mathrm{projects/anegada} \mathrm{[accessed} 12$ July 2021].

Meléndez-Ackerman, E. (2008) Diet of feral goats in Mona Island reserve, Puerto Rico. Caribbean Journal of Science, 44, 199-205.

Meudt, H.M. \& Clarke, A.C. (2007) Almost forgotten or latest practice? AFLP applications, analyses and advances. Trends in Plant Science, 12, 106-117.

Missouri Botanical Garden (2015) TROPICOS. Missouri Botanical Garden, St Louis, USA. tropicos.org [accessed 1 May 2015].
Mitchell, N.C.C. (1999) Effect of introduced ungulates on density, dietary preferences, home range, and physical conditions of the iguana (Cyclura pinguis) on Anegada. Herpetologica, 55, 7-17.

Murry, B.A., Colón-Merced, R.J., Colón-Rivera, R., Fury, C., García-Bermúdez, M.A., Herrera-Giraldo, J.L. et al. (2020) An overview of the socio-ecological system of cays and islets in the U.S. Caribbean and their vulnerability to climate change. In Encyclopedia of the World's Biomes, Volume I (eds M. Goldstein \& D. DellaSala), pp. 126-144. Elsevier, Amsterdam, The Netherlands.

Myers, N. (1988) Threatened biotas: 'hot spots' in tropical forests. The Environmentalist, 8, 187-208.

New York Botanical Gardens (2015) Virtual Herbarium. sciweb. nybg.org/science2/vii2.asp.html [accessed 1 May 2015].

Pimm, S.L. \& JoppA, L.N. (2015) How many plant species are there, where are they, and at what rate are they going extinct? Annals of the Missouri Botanical Garden, 100, 170-176.

Pritchard, J.K., Stephens, M. \& Donnelly, P. (2000) Inference of population structure using multilocus genotype data. Genetics, 155, 945-959.

Ricketts, T.H., Daily, G.C., Ehrlich, P.R. \& Michener, C.D. (2004) Economic value of tropical forest to coffee production. Proceedings of the National Academy of Sciences of the United States of America, 101, 12579-12582.

Rivera-Ocasio, E., Aide, T.M. \& McMillan, W.O. (2002) Patterns of genetic diversity and biogeographical history of the tropical wetland tree, Pterocarpus officinalis (Jacq.), in the Caribbean basin. Molecular Ecology, 11, 675-683.

Royal Botanic Gardens, Kew (2016) The State of the World's Plants Report - 2016. Royal Botanic Gardens, Kew, Richmond, UK.

SCHOFIELD, E.K. (1989) Effects of introduced plants and animals on Island vegetation: examples from the Galapagos Archipelago. Conservation Biology, 3, 227-238.

SHEPHERD, V.A. (2009) Livestock and sugar: aspects of Jamaica's agricultural development from the late seventeenth to the early nineteenth century. The Historical Journal, 34, 627.

UKOTs Team (2020) UKOTs Online Herbarium. Facilitated by the Royal Botanic Gardens, Kew (eds M.A. Hamilton \& S. Bárrios). brahmsonline.kew.org/UKOT [accessed 24 September 2020].

UNEP (2000) Conference of Parties to the Convention on Biological Diversity. Decision V/10. Global Strategy for Plant Conservation, Secretariat of the Convention on Biological Diversity, Montreal, Canada.

UNEP (2010) Conference of Parties to the Convention on Biological Diversity. Decision X/17. Consolidated update of the Global Strategy for Plant Conservation 2011-2020. Secretariat of the Convention on Biological Diversity, Montreal, Canada.

University of Oxford (2015) Botanical Research and Herbarium Management System (BRAHMS). herbaria.plants.ox.ac.uk/bol/ brahms/Software/Terms [accessed 5 August 2015].

Veitch, C.R. (1999) Survival of the Anegada Rock Iguana: an Assessment of Threats and Possible Remedial Actions. Roadtown, Tortola, British Virgin Islands.

Vos, P., Hogers, R., Bleeker, M., Reijans, M., van de Lee, T., Hornes, M. et al. (1995) AFLP: a new technique for DNA fingerprinting. Nucleic Acids Research, 23, 4407-4414.

Wittenberg, R. \& Cock, M.J.W. (2001) Invasive Alien Species: A Toolkit of Best Prevention and Management Practices. CABI, Wallingford, UK.

Wolf, C.A., Young, H.S., Zilliacus, K.M., Wegmann, A.S., McKown, M., Holmes, N.D. et al. (2018) Invasive rat eradication strongly impacts plant recruitment on a tropical atoll. PLOS ONE, 13 , e0200743. 